\title{
Transforming Place, Time and Person?: Mobile Telephones and Changing Moral Economies in the Western Pacific
}

\author{
Margaret Jolly
}

The chapters in this volume traverse the countries of Papua New Guinea, Fiji and Vanuatu and relate questions about the political economy and regulatory regimes of companies like Digicel and Vodafone in these three states to the embodied experiences of consumers: young and old, rural and urban, female and male. They are consummately connected (excuse the bad pun). I will focus on three dimensions of this connection by looking at the way in which these chapters reveal how mobile phones have transformed the experience of place, time and person, and how they are situated in changing moral economies.

\section{Place}

All chapters attest to the rapid and extensive rollout of mobile telephones across the region. For instance, in Papua New Guinea, the largest country in the region, Digicel expanded from c. 300,000 customers in 2007 to c. 3,400,000 in 2014, and has established about 1,800 signal towers across the country and holds c. 90-95 per cent of the market (Dan Jorgensen, Chapter 3). Holly Wardlow (Chapter 2) observes that, between her departure in 2006 and her return in 2010, villages in the Tari Basin (PNG Highlands) moved from having no mobile phones to having extensive coverage and ownership. In this period, Digicel was expanding at an astonishing rate, compared to its state rival Bemobile, which was 
hampered by ageing infrastructure, state inertia and messy politics. Vaulting fast in this race with their rival, Digicel used many techniques honed by its experience in the Caribbean that were designed to entice not just the urban rich but the rural poor with cheap phones and systems designed to accommodate the low credits of most users (like the free 'call me' and 'credit me' systems).

Mobile phone coverage in many parts of Papua New Guinea (as in much of rural Vanuatu and Fiji) has preceded the delivery of running water, sewage or electricity. Thus, in many rural regions, mobile phone batteries can only be recharged at available public outlets (e.g. in airports, stores or government departments), at improvised charging stations at markets or by using solar power. As the map that accompanies Jorgensen's chapter shows, and David Lipset (Chapter 1) observes for Murik Lakes in the Sepik, coverage is not total - there are still some villages both on the mainland and offshore islands of Papua New Guinea that are not regularly on the grid. But, compared to Bemobile's coverage, which is defined by major highways and trunk roads, Digicel has penetrated into much of the rural and remote highlands and islands of the nation. The company's rapacious desires to expand their coverage, market dominance and consumer allure has been matched by a strong desire on the part of many of Papua New Guinea's citizens and consumers to be connected. This passion for connection is equally felt in Vanuatu and in Fiji (see Horst , Chapter 4; Kraemer, Chapter 5; Taylor 2015).

But, we might ask for all three countries, how far has this transformed or even revolutionised notions of ples: ideas of national citizenship in relation to ethnic and regional differences and boundaries of belonging?

In her chapter on Fiji, Heather Horst evokes not only a contest between the rival companies of Vodafone and Digicel but also a contest between competing boundaries of belonging, from the local to the national to the global. These are not so much nesting scales but contesting scales of place. She focuses on how the longer established Vodafone, which still commands most of the Fiji market (c. 80 per cent), has deployed a series of branding strategies that evoke a sense of belonging to or being part of Fiji: to the Fiji National Rugby Team, bati or Fijian warriors, the natural beauty of the islands, local popular music (such as Talei Burns) and ultimately the supremacy of God in these islands (see Horst's discussion of Vodafone advertising). Vodafone has also astutely invested in charitable trusts supporting local community projects and, more recently, instigated 
the localisation of the company by accepting the 79 per cent stake of the National Provident Fund, the country's main pension scheme. All of this combines to secure the semiotic links of Vodafone to the place of Fiji and its future trajectory. In Horst's view, the moral economy that Vodafone promotes is focused on citizens more than consumers in the citizenconsumer conjugation.

Digicel, which launched later in October 2008, tried rather unsuccessfully to break this conjugation between the brands of Vodafone and the Fiji state, first by challenging the monopoly on the link to rugby but also by changing the palette of their brand to have the blue of the Fiji flag echoed in the last letters of their brand name. They also vaunted the fact of their entry into the market through liberalisation as a manifestation of freedom and choice and, as in other countries, pitched to the rural poor through both their extensive coverage and their credit systems. (Vodafone first focused on urban centres but increased its rural coverage in anticipation of and in continued competition with Digicel). But there were some strategic slips in Digicel's branding: using visual images that offended the conservative dress codes of older Fijians (e.g. tank tops, swimsuits; see Horst, Chapter 4) and an undue reliance on Caribbean music and popular culture, rather evoking generic 'brown islanders' than specifically Fijians (Horst, Chapter 4). Perhaps the greater resonance of the global rather than the national in their brand might partially explain their pre-eminence in the youth and business markets. If this brand loyalty continues, they may expand their market share in the future beyond their present 20 per cent holding. ${ }^{1}$ Horst considers that Digicel promotes a moral economy more attuned to people's identity as consumers than citizens in the conjugation of consumer-citizens.

Other chapters in this volume deal more intimately with how mobile phones have transformed experiences of place in specific locales: from the towns of Port Moresby and Goroka (Foster, Chapter 6) and Port Vila (Kraemer, Chapter 5) to the remote villages of the Sepik (Lipset, Chapter 1) and the Highlands and Western Province (Jorgensen, Chapter 3; Wardlow, Chapter 2). The passion for connection beyond the boundaries of embodied belonging to place and kin is manifest.

1 In situating the rival brands of Vodafone and Digicel in Fiji we might compare the national versus global resonance of the contesting Christian brands of Methodism and Seventh-day Adventism discussed so persuasively by Hiro Miyazaki in the context of Suvavou and beyond in Fiji (Miyazaki 2004; see also Tomlinson 2009). 
Lipset records the keen desire of Murik Lakes' people to seek connections, using surrogate ladders and platforms and beach hot spots to do so. The most reliable hot spot is in an appropriately liminal zone, a doorway in a household where a private handset is made available for public use, for whatever personal calls are needed by other villagers. Lipset interprets this as an extension of a moral economy dominated by the gift and the reciprocity of kin - most calls being about familial health and illness or about coordinating movements of kin, neighbours and business partners in time and space. The mobile phone palpably allows a compression of both space and time.

Wardlow (Chapter 2) discerns a rather different pattern in the Tari Basin of Highlands Papua New Guinea whereby mobile phones enable a novel connectedness between kin separated not just by geography but by gendered power and proprieties. Mobile phones enable women to keep contact with natal kin and, especially, mothers, sisters and daughters in a way that virilocal residence and husbands' proscriptions inhibited or even impeded in the past. But, beyond these reanimated kin connections there is also, for both women and men, the new phenomenon of intimate strangers known as phone friends (see below). Phone friends also loom large in the mobile telephone networks of young men in Port Vila, Vanuatu (Kraemer, Chapter 5). By Daniela Kraemer's account, based on fieldwork in the settlement of Freswota, young men feel defined by their urban settlement and increasingly detached from home islands and distant kin; the escalating costs of inter-island travel has made travel within the archipelago far more difficult than in the past.

Jorgensen's chapter extends the spatial reference beyond the national and the regional to the global. Using the case study of a man called Toby, ${ }^{2}$ he shows both the paradox and, indeed, the deep ambivalence about the ubiquity and daily necessity of the mobile phone. Toby is suspicious of the immoral or even Satanic potential of mobile phones and the capacity of the 'mobile system' to yield universal surveillance and, thereby, the expanded efficacy of global superpowers like the United States and China. This may be a personal and even an idiosyncratic view, combining Biblical stories derived from the Book of Daniel with fears about undue foreign influence in the extractive industries of Papua New Guinea and the spectre of world government. But Toby is not alone in his fears. In both Papua

2 All names used by authors in this volume are pseudonyms. 
New Guinea and Vanuatu, mobile phones are regularly associated with moral ills, many of which are thought to have foreign origins and are seen as signs of the 'end times' (Kraemer, Chapter 5; Taylor 2015).

\section{Time}

Several chapters allude to how mobile phones are intimately entangled with dominant narratives about, and the embodied experience of, time. Jorgensen points to how mobile phones have become linked to widely circulating apocalyptic narratives about the end times, 'a low background hum in PNG popular culture', which are especially pronounced in evangelical Christian and HIV contexts (see Wardlow 2006). In several chapters in this volume, and in previous studies, the labile potential of the mobile phone has been seen as a conduit or even a cause of loosened sexual morality, of illicit love, of rape and sexual harassment and of sorcery (see Andersen 2013; Taylor 2015). All of these are condensed in widespread imaginings of the transformations of modernity through the enhanced spatio-temporal mobility effected by the mobile phone.

Robert Foster's chapter witnesses another temporal pulse at work: the time-discipline inherent in pervasive prepaid schemes and transfer of credits that enable access to mobile phones by those who are resource poor. Inspired both by the earlier writings of Thomson on the moral economy of time thrift in factories and textile mills and the more recent writings of Schüll on Las Vegas casinos, he suggests that the time discipline encouraged by prepaid schemes assumes individual fiscal responsibility but simultaneously solicits excess consumption. The combination of using only what one has already paid for and the mandatory expiry dates of SIM cards, credits and alluring bundle deals leads to a logic of 'use it or lose it' and of stimulating subscribers 'to consume more in less time'. So, rather than mobile phones being primarily instruments of pleasurable, leisurely communication, their use becomes rather the disciplined work of consumption (evoked in the singular case of Lucy). As Foster suggests, 'The notion of time thrift ... seems perverted when people stay awake until the wee hours of the morning to make phone calls'. The author of a letter to a PNG newspaper asked whether Digicel thought subscribers like him were nocturnal, like flying foxes. Foster also shows how Digicel's marketing regimes underscore the pervasive practice of seeking and giving phone credits: through using missed calls to say 'call me' and through the 
ease of sending credit to another user. Credit requests might be refused (suggesting avoidance or resistance), always agreed to or, more often, selectively agreed to in a way that signals and secures familial, friendship and romantic attachments. But, in all this, the company's regimes and personal dispositions interact so that, rather than being a respite from work, performing personal and social relations is a form of 'work' in Papua New Guinea in the era of late capitalism.

\section{Person}

Finally, I want to turn to questions about whether the pervasive use of mobile phones in these three countries has been influential in transforming notions and values of the person, from an emphasis on more relational to more individual forms. Lipset's chapter addresses this question most directly, pondering whether the voices of its subscribers are modern, rational and individuated. Mobile technology has the potential for greater individual autonomy, privacy, anonymity or even outright dissimulation. For instance, Andersen (2013) has written about gesfaia (Tok Pisin for phone calls made by anonymous, primarily male, callers to unknown numbers) as experienced by women students at a nursing school in the PNG Highlands. Such anonymous phone encounters, like the Internet, allows space for individualist fantasies about identity and 'lies and trickery' on both sides, even if those involved eventually become longterm phone friends. Lipset claims gesfaia 'suggest the rise of a decidedly Melanesian form of individualism, one that is free of social constraints imposed by kin and foreground the ambiguity of contemporary urban life'. However, Lipset also argues that the new connectivity is informed by the moral economy that predates it: 'mobile phones expand the physical, but more importantly, the moral, space of kinship'. For the people of Murik Lakes, mobile telephony 'expands space and time informed by normative, kinship-based values and the moral economy of the gift'. The space-time compression characteristic of modernity and, particularly, mobile telephony thus simultaneously generates a new cosmopolitan individualism and the maintenance of place-based collectivities between rural locales and urban diasporas. Lipset's analysis is exemplified by Venis and Eric's 'accidental kiosk' in the doorway of their house in a Murik Lakes village, whereby their handset was not treated as private property 
but freely shared with many others in the village, primarily to enable and perpetuate the density of kin relations at a distance (see above, and see also Lipset 2013, 2017; Telban and Vávrová 2014).

Kraemer's portrait of the use of mobile phones by unemployed and poorly educated young men in Port Vila suggests a rather different scenario (see also Kraemer 2015). The young men with whom she works are marginalised from both kastom and commodity economies, lacking both the resources generated by access to the land and kinship of home islands and the cash and commodities accessible through paid work or business. Even though they are barely eking out a living, they spend much of their time and scarce money on relentless quests for receiving and spending phone credits. For them, mobile phones are 'less about communication with family and friends than it is about broadening one's network of social relationships'. This extends to making random calls and sending texts to anonymous strangers in the hopes of accumulating more 'phone friends' and creditors. Such expansive networking can, as in the case of Alfred, become burdensome - too many contacts, too many texts - and thus the need to focus selectively on more valued contacts.

As Kraemer discerns, these dynamics are modelled on entrenched 'Melanesian' idioms of how generosity and strategic gifting yields status. But novel dimensions emerge in this situation of urban precarity: rather than re-inscribing existing relations of place and kin connection, these young men develop more egocentric, individualist networks of cashedup kin and neighbours, politicians and young women who evince a romantic interest. Giving and receiving phone credits signals hope of developing relationships, of positive future acts of generosity, hospitality and loyalty on the part of the other. But a cessation of such reciprocity signals the devaluation or even termination of a relationship, often and most graphically in romantic attachments. The scenario of revenge and retaliation that developed between Toby (on behalf of his friend) and a young woman, Rose, reveals how phone credit exchanges and refusals are ways for young men to perform power and masculine potency in novel contexts, at a remove from models of relational persons embedded in place or kinship.

Wardlow's chapter evinces graphic evidence of how mobile phones are as much affective as effective technologies. Like Lipset (Chapter 1) and Andersen (2013), she attests to how mobile phones are used in heterosexual romantic liaisons between strangers at a distance, in which both partners 
can relish teasing, flirting and the potential for dissimulation, as well as sharing intimate stories of their daily lives. But her focus is on the phone friendships cultivated by women living with HIV, for the most part mature, middle-aged women. Such friendships typically originated in random anonymous calls during which the HIV-positive women did not hide their status but openly declared it to their phone friends, and shared with them intimate stories about their daily lives and, in particular, their sufferings not just from illness but from stigma and familial or communal exclusion. These phone friends thus became intimate strangers with whom it was possible to share troubles and trauma and to gain solace and support, but who were also at a safe distance. Without the 'thick relations' of kinship, often congested by anger and anguish, women could be easily affectionate - talking and laughing and relieving the stresses that they were told might reanimate the illness. The contraction of the social world experienced by many HIV-positive people was thus expanded again through such individual networks. The theft of a phone or the loss of the numbers of crucial phone friends could, as in the case of Lucy, be a source of anguish and deep personal loss.

In conclusion, this volume delivers innovative insights into the recent, short life of mobile phones in the Pacific and offers interesting comparisons with the broader, vastly accumulating literature on Asia, Africa and the Caribbean (see, for instance, Doron and Jeffrey 2013; Horst and Miller 2006). They have obviously had a profound impact on social relations in these three Pacific states, reconfiguring relations of place and time and the prevailing character and values of personhood. This is likely to continue into the future. This set of essays is distinctive in the way that, through a series of grounded ethnographies, it connects the political economies and regulatory regimes of mobile phone companies with how mobile phones are being used in everyday lives. The chapters by Horst and Foster reveal the strategies used by companies like Digicel and Vodafone to create an aesthetic of brand cultures, linked to ideas of the nation and modernity (through consumption as much as citizenship) and how they model systems consonant with prevailing patterns of use and subscriber desires. But the ways in which mobile phones permeate everyday lives and the moral worlds of subscribers far exceed these strategies, in conversations between distant kin and intimate strangers; in secretive, quotidian confessions and distantiated, dissimulating fantasies; and in imaginations of both utopic and dystopic futures presaging the 'end times'. The social 
life of mobile phones in the Pacific palpably reveals how they are not just an instrumentally effective technology but also a much-desired 'affective technology'.

This is part of a wider pattern of commodification of desire in latecapitalist culture:

the emergence of brands and branding cultures moves beyond the shift to commodification to offer immaterial products such as emotion and affect as well personalities and values, factors that have become essential to the inner workings of global capitalism. Through these branding activities, users are transformed into consumers and citizens, or consumer-citizens, who use the products of a particular company and come to identify with the brand that produces or distributes a particular product. (Horst, Chapter 4)

But, as Horst suggests, this is not just based on the contracts between companies and consumers but also depends upon the relationships constituted with the state and the character of the regulatory environment:

the cultivation of consumer-citizens is as much about the semiotics of emotion and imagery of belonging used in advertising as it is about ownership structures and regulatory bodies. Notions of national belonging are thus intertwined with telecommunications infrastructures. (Horst, Chapter 4)

The state personified is thus not just an inert background but an active agent in competing moral economies involving companies, consumers and the state.

\section{References}

Andersen, B. 2013. Tricks, Lies and Mobile Phones: 'Phone Friend' Stories in Papua New Guinea. Culture, Theory and Critique, 54(3): 318-34. doi.org/10.1080/14735784.2013.811886

Doron, A. \& R. Jeffrey 2013. The Great Indian Phone Book: How the Cheap Cell Phone Changes Business, Politics and Daily Life. Cambridge, Massachusetts: Harvard University Press.

Horst, H.A. \& D. Miller 2006. The Cell Phone: An Anthropology of Communication. New York: Berg. 
Kraemer, D. 2015. 'Do You Have a Mobile?' Mobile Phone Practices and the Refashioning of Social Relationships in Port Vila Town. The Australian Journal of Anthropology (TAJA), 28(1): 39-55. doi.org/ $10.1111 /$ taja.12165

Lipset, D. 2013. Mobail: Moral Ambivalence and the Domestication of Mobile Telephones in Peri-Urban Papua New Guinea. Culture, Theory and Critique 54(3): 335-54. doi.org/10.1111/j.1548-1352.2 009.01031.x

2017. Yabar: The Alienations of Murik Men in a Papua New Guinea Modernity. Cham, Switzerland: Palgrave Macmillan.

Miyazaki, H. 2004. The Method of Hope: Anthropology, Philosophy and Fijian Knowledge. Redwood City CA: Stanford University Press.

Taylor, J.P. 2015. Drinking Money and Pulling Women: Mobile Phone Talk, Gender and Agency in Vanuatu. Anthropological Forum, 25: 1-16. doi.org/10.1080/00664677.2015.1071238

Telban, B. \& D. Vávrová 2014. Ringing the Living and the Dead: Mobile Phones in a Sepik Society. The Australian Journal of Anthropology (TAJA), 25(2): 223-38. doi.org/10.1111/taja.12090

Tomlinson, M. 2009. In God's Image: The Metaculture of Fijian Christianity, vol. 5, The Anthropology of Christianity. Berkeley: University of California Press.

Wardlow, H. 2006. Wayward Women: Sexuality and Agency in a New Guinea Society. Berkeley: University of California Press. 
This text is taken from The Moral Economy of Mobile Phones: Pacific Islands Perspectives, edited by Robert J. Foster and Heather A. Horst, published 2018 by ANU Press, The Australian National University,

Canberra, Australia.

doi.org/10.22459/MEMP.05.2018.08 